- RAM, REV. ADM. MACKENZIE, 15(3), Edição Especial • SÃO PAULO, SP • MAIO-JUN. 2014 • ISSN 1518-6776 (impresso) • ISSN 1678-6971 (on-line) • http://dx.doi.org/10.1590/1678-69712014/administracao.v15n3p101-131. Submissão: 12 out. 2013. Aceitação: 9 maio 2014.

\title{
1 AS ALIANÇAS ESTRATÉGICAS NO PICADEIRO DA ARTE/NEGÓCIO CIRCENSE
}

\author{
EDSON ANTUNES QUARESMA JÚNIOR \\ Doutorando em Administração do Centro de Pós-Graduação e Pesquisas em Administração \\ da Universidade Federal de Minas Gerais (UFMG). \\ Professor do Departamento de Ensino do Instituto Federal de Educação, Ciência \\ e Tecnologia do Norte de Minas Gerais (IFNMG).
} Fazenda Varginha, Km 2, Rodovia Salinas/Taiobeiras, Salinas - MG - Brasil - CEP 39560-000 E-mail: edsontunes@hotmail.com

EVERTON RODRIGUES DA SILVA

Doutorando em Administração do Centro de Pós-Graduação e Pesquisas em Administração da Universidade Federal de Minas Gerais (UFMG). Avenida Antônio Carlos, 6.627, sala 4.012, Pampulha, Belo Horizonte - MG - Brasil - CEP 31270-901

E-mail: everton.rsilva@gmail.com

\section{ALEXANDRE DE PÁDUA CARRIER}

Doutor em Administração pelo Centro de Pós-Graduação e Pesquisas em Administração da Universidade Federal de Minas Gerais (UFMG).

Professor titular do Centro de Pós-Graduação e Pesquisas em Administração da Universidade Federal de Minas Gerais.

Avenida Antônio Carlos, 6.627, sala 4.070, Pampulha, Belo Horizonte - MG - Brasil - CEP 31 270-901

E-mail: alexandre-carrieri@ufmg.br

Este artigo pode ser copiado, distribuído, exibido, transmitido ou adaptado desde que citados, de forma clara e explícita, o nome da revista, a edição, o ano e as páginas nas quais o artigo foi publicado originalmente, mas sem sugerir que a RAM endosse a reutilização do artigo. Esse termo de licenciamento deve ser explicitado para os casos de reutilização ou distribuição para terceiros. Não é permitido o uso para fins comerciais. 


\section{RESUMO}

O objetivo do artigo é estudar a contribuição das alianças para a longevidade das empresas, tendo como objeto um campo quase esquecido pela administração, as organizações circenses. A despeito de sua importância econômica e simbólica, tal setor é pouco estudado sob o ponto de vista de suas práticas gerenciais. Nesse sentido, o problema proposto para exame é identificar em que medida as unidades pesquisadas realizam alianças capazes de gerar benefícios competitivos. O foco de investigação são as parcerias com licenciadas de marcas ícones do entretenimento infantil nacional, como Patati Patatá, Galinha Pintadinha e Turma da Mônica. Como objetivo secundário, pretende-se gerar subsídios para pesquisas futuras acerca do circo, razão pela qual o referencial teórico sobre alianças organizacionais foi elaborado em uma perspectiva ampla, posição coerente com o estágio incipiente da produção científica no segmento. Metodologicamente, adotou-se uma abordagem qualitativa com base em entrevistas em três circos de grande porte, da Região Sudeste. As informações foram trabalhadas por meio da análise do discurso. Os casos estudados apontaram que as alianças são uma fonte de valor por proporcionarem ganhos de performance nas dimensões: econômica (redução de risco, maximização dos ativos e de receita), de diferenciação competitiva (oriunda da partilha de recursos), e de desenvolvimento de capacidade adaptativa, denotada pelo senso de oportunismo decorrente das parcerias. Outro achado relevante diz respeito à presença antiga das alianças no cotidiano dos circos. Também foram apontados caminhos para esforços acadêmicos posteriores sobre: I. os modos de existência das organizações circenses; 2 . a fluidez e extensão dos limites organizacionais; 3. a relação de subordinação e os jogos de poder entre as partes envolvidas, com destaque para o exame da ambivalência gerada pelas alianças, expressa pelo paradoxo da conquista de flexibilidade versus a restrição competitiva; 4. a influência dos laços sociais na escolha e na coordenação das alianças; 5. as relações contratuais na indústria circense; 6. o aprofundamento da identificação dos recursos compartilhados. Por fim, cabe pontuar que as constatações levantadas não podem ser generalizadas, dado o recorte da população investigada. 


\section{PALAVRAS-CHAVE}

Alianças estratégicas. Circos. Parcerias. Organizações circenses. Entretenimento familiar.

\section{LUZ SOBRE O PICADEIRO}

No momento atual, as modificações na oferta e no consumo de produtos culturais - proliferação de atrativos substitutos (entretenimento doméstico, jogos em rede, TV paga etc.), barateamento de aparelhos eletrônicos, melhorias tecnológicas neste e aumento da oferta de crédito para consumo desses bens (Reis, 2007) - exercem pressão para que as atividades artísticas voltadas para a indústria do entretenimento repensem seu posicionamento e seus meios de sobrevivência.

Dentro desse contexto, o objetivo do presente artigo é estudar a contribuição das alianças organizacionais para a longevidade das empresas, tendo como objeto empírico um campo quase esquecido pela administração, as organizações circenses ${ }^{\mathrm{I}}$. Essas organizações são entendidas como uma unidade produtiva com uma clara divisão do trabalho elaborada em torno do espetáculo (Magnani, 2003) e materializada em uma pluralidade de existências cotidianas: variam conforme a capacidade de público, a formação dos artistas, a concepção e o modo de produção do espetáculo, a forma de gestão, entre outros.

Desse modo, buscou-se levantar evidências sobre como os circos da Região Sudeste do Brasil têm incorporado as alianças para se manter como negócio, isto é, como opção de entretenimento para o consumo familiar. A despeito da importância econômica e simbólica da atividade circense, tal setor é pouco estudado sob o ponto de vista de suas práticas gerenciais, especialmente aquelas relativas aos motivadores da formação de acordos de cooperação. Nesse sentido, o problema fundamental proposto para exame é identificar em que medida as unidades pesquisadas realizam alianças capazes de gerar benefícios competitivos e consolidar

\footnotetext{
Vários acadêmicos, no Brasil, empreenderam esforços para verificar as contribuições das alianças para a perpetuação das firmas em diferentes segmentos. Podem ser citados, como exemplo, os setores aéreo (Pereira \& Marujo, 20II); supermercadista (Estivalete, Pedrozo, \& Begnis, 2008; Laimer \& Laimer, 2009; Oliveira, Resende, \& Carvalho, 20II); de eletroeletrônicos (Balbinot \& Marques, 2009); automobilístico (Rossi \& Póvoa, 2008); da indústria têxtil (Carrão, 2004); de biocombustíveis (Almeida \& Machado, 2013); de petróleo e gás (Pellegrin, Balestro, Antunes, \& Caulliraux, 2007); de varejo de material de construção (Castro, Bulgacov, \& Hoffmann, 20II); da indústria cinematográfica (Kirschbaum, 2006; Silva, Lopes, \& Muniz, 20I3); entre outros. Mas não foi encontrada pesquisa acadêmica em administração que investigasse o setor dos circos no Brasil.
} 
o seu posicionamento no segmento em que atuam. O foco de investigação são as parcerias que os circos entrevistados realizam com empresas licenciadas de marcas ícones do entretenimento infantil nacional, como Patati Patatá, Galinha Pintadinha e Turma da Mônica.

Como objetivo secundário, pretende-se, por meio desse primeiro esforço de aproximação, gerar subsídios para pesquisas em estudos organizacionais acerca do objeto circo e também sobre as abordagens teóricas relacionadas às alianças empresariais, capazes de proporcionar uma melhor compreensão do papel desse fenômeno nas organizações circenses. Assim, o referencial teórico elaborado volta-se para uma perspectiva mais ampla do campo de estudos sobre alianças, perpassando diversas linhas teóricas, na intenção de abrir caminhos para a exploração de oportunidades para pesquisas futuras.

O artigo está dividido em cinco partes. Após esta introdução, faz-se uma revisão teórica sobre as alianças organizacionais, ao que se segue o itinerário metodológico adotado. O campo empírico foi observado por um viés qualitativo, alcançado por meio de entrevistas em profundidade com três pessoas envolvidas na área administrativa e dois artistas, atores representativos de três circos de grande porte, com base na Região Sudeste. As informações foram trabalhadas por meio da análise do discurso.

$\mathrm{Na}$ parte final, apresentam-se a análise e a discussão dos resultados. No fechamento do trabalho, são lançadas as considerações finais, nas quais se retomam os objetivos e as contribuições do artigo e se elucidam as limitações dele, bem como os apontamentos para pesquisas futuras.

\section{ALIANÇAS ORGANIZACIONAIS}

A tarefa de escrever (academicamente) sobre o tema em questão impõe desafios, entre eles a escolha de uma lógica de pensamento que norteará a leitura de conceitos e teorias e sua posterior compilação, a fim de que o texto final se concretize. Preece (I995) oferece um arcabouço didático e eficaz para tal iniciativa. $\mathrm{O}$ autor entende que as relações interorganizacionais ${ }^{2}$ devem ser estudadas sob uma ótica tridimensional, formada por:

- Estrutura: como a aliança será desenhada na prática?

(104) - Objetivos: qual é a contribuição da aliança para o direcionamento geral e as capacidades da empresa?

Preece (I995) utiliza a expressão alianças estratégicas internacionais (AEIs), simplesmente por focar seu artigo na utilização das alianças como meio de expansão internacional. 
- Funções: quais são os benefícios/motivações das alianças? Exemplos: acesso ao mercado, desenvolvimento tecnológico, compartilhamento da produção, de riscos, acesso a recursos financeiros etc.

No presente trabalho, a dimensão estrutura será primeiramente abordada sob o nome de "Conceitos e tipologias". Na sequência, os objetivos, ou motivação geral, serão destrinchados, examinando-se as múltiplas escolas conceituais que formularam sua "teoria geral" para explicar o "pano de fundo" estratégico impulsionador das alianças. As funções serão descritas no subtópico "Principais benefícios das alianças organizacionais".

\subsection{CONCEITOS E TIPOLOGIAS}

As alianças estratégicas são um arranjo cooperativo voluntário entre empresas, baseado em troca, compartilhamento ou codesenvolvimento de produtos, serviços e tecnologias. Esses arranjos ocorrem por variados motivos e assumem uma multiplicidade de formas (Gulati, I998), entre elas: joint ventures; acordos de licenciamento, de comercialização, de distribuição; contratos e projetos de pesquisa e desenvolvimento (P\&D); ações compartilhadas de marketing; consórcios; subcontratação (Eiriz, 200I; Li, Qian, \& Qian, 2013; Tsang, I998). Tais configurações podem ser categorizadas nos tipos: sem participação acionária (a gestão entre as partes é feita por acordos de licenciamento, de fornecimento e de distribuição); com participação acionária (existe a parceria entre as partes A e B, mas a empresa A tem participação acionária na B); e joint venture (ou união de risco, em que as parceiras criam uma empresa independente), adotando-se proposta de Barney e Hesterly (20II).

Das e Teng (2000) propõem outra tipologia para as possíveis configurações das alianças: joint ventures; alianças com participações minoritárias; alianças baseadas em contratos bilaterais; alianças baseadas em contratos unilaterais. As últimas são frequentes em situações em que ocorre transferência de direitos de propriedade, como em licenciamentos, contratos de distribuição, de P\&D etc. Sua principal característica é que o participante cumpre as suas obrigações de forma mais independente dos outros, com baixa necessidade de coordenação ou colaboração. Por sua vez, as alianças bilaterais demandam a alocação de recursos pelos parceiros e um trabalho em conjunto realizado sistematicamente. A exigência por integração é maior. A posse de recursos, a disposição da empresa em cooperar (algumas vezes, a organização deve proteger os seus recursos, e, por isso, seu potencial de integração fica limitado) e as necessidades da empresa orientarão a escolha da estrutura em que a colaboração se concretizará. 
Já Grandori e Soda (I995), a partir de um extenso estudo bibliográfico, sugerem que a diversidade de arranjos interfirmas pode ser representada conforme explicitado no Quadro I.

\section{QUADRO I}

\section{TIPOLOGIA DE REDES EMPRESARIAIS}

\begin{tabular}{|c|c|c|}
\hline TIPO DE REDE & $\begin{array}{l}\text { DESDOBRAMENTOS } \\
\text { DO TIPO DE REDE }\end{array}$ & DESCRIÇÃO \\
\hline \multirow{2}{*}{$\begin{array}{l}\text { 1. Redes sociais: } \\
\text { relações regidas por } \\
\text { contrato informal }\end{array}$} & Simétricas & $\begin{array}{l}\text { Processo decisório mais justo e equilibrado, com } \\
\text { maior fluidez na comunicação. }\end{array}$ \\
\hline & Assimétricas & Presença de um agente central decisório. \\
\hline \multirow{2}{*}{$\begin{array}{l}\text { 2. Redes burocráticas: } \\
\text { existência de } \\
\text { acordo formal entre } \\
\text { as partes }\end{array}$} & Simétricas & $\begin{array}{l}\text { Associações que requerem nível de complexidade } \\
\text { contratual básico. Exemplo: associações } \\
\text { comerciais. }\end{array}$ \\
\hline & Assimétricas & $\begin{array}{l}\text { Necessidade de maior detalhamento contratual. } \\
\text { Exemplo: licenciamento e franquia. }\end{array}$ \\
\hline \multirow{2}{*}{$\begin{array}{l}\text { 3. Redes proprietárias: } \\
\text { existência de } \\
\text { acordo formal } \\
\text { entre as partes e } \\
\text { comprometimento } \\
\text { de capital }\end{array}$} & Simétricas & $\begin{array}{l}\text { Joint ventures criadas com participações } \\
\text { acionárias equilibradas entre as partes. }\end{array}$ \\
\hline & Assimétricas & $\begin{array}{l}\text { Associações do tipo venture capital, envolvendo } \\
\text { um investidor e uma firma. Normalmente, } \\
\text { relaciona-se a projetos de tecnologias avançadas. }\end{array}$ \\
\hline
\end{tabular}

Fonte: Elaborado pelos autores com base em Grandori e Soda (I995).

Os autores interpretam o fenômeno das alianças a partir de três dimensões: grau de formalização, nível de centralização e participação acionária. Quanto à primeira, as redes ${ }^{3}$ podem ser regidas por contratos formais (burocráticas ou proprietárias) ou informais (sociais). Quanto à segunda, podem ser simétricas - ou seja, constituídas por empresas que preservam sua interdependência (maior nível de descentralização de poder) - ou assimétricas, nas quais há uma forte centralização do poder (é razoável dizer que as firmas são

Tal palavra é utilizada de modo bastante amplo, significando transações relacionais entre atores, motivadas pela ideia de que, dificilmente, determinados objetivos poderiam ser atingidos atuando de modo isolado. Por isso, entende-se que, no conceito apresentado pelos autores, redes e alianças podem ser utilizadas como palavras sinônimas. 
semi-independentes). A última dimensão diz respeito ao envolvimento de participação acionária (ou outra forma de direito de propriedade), sendo chamada de redes proprietárias.

\subsection{DIVERSIDADE TEÓRICA DOS ESTUDOS SOBRE ALIANÇAS ORGANIZACIONAIS}

O desenvolvimento dos estudos sobre alianças se deu sob variados matizes. Diversos acadêmicos, como Grandori e Soda (I995), Vale e Lopes (20I0) e Balestrin, Verschoore e Reyes (20I0), preocuparam-se em lançar luz nesse processo.

Grandori e Soda (I995) produziram um artigo seminal sobre os múltiplos enfoques em alianças, mapeando as principais vertentes e suas respectivas interpretações sobre o fenômeno colaborativo.

A primeira abordagem identificada é a da economia industrial, que utiliza o conceito de custos de produção (escala, escopo, especialização e experiência) como variável central na avaliação da eficiência de uma rede. Na sequência, foi apresentada a abordagem histórica e evolucionária, que, além dos custos de produção, considera o papel das novas tecnologias na formação das redes. Já a perspectiva da economia organizacional acrescenta a ideia da redução dos custos de coordenação das atividades, proporcionada pelos arranjos interempresariais.

Outra perspectiva, a organizacional, foca em estudos prescritivos e descritivos, apresentando os seguintes indicadores para medição do grau de sucesso de uma aliança: diferenciação entre os participantes da rede (distância entre objetivos, orientações, valores, crenças e perfis organizacionais); intensidade da interdependência entre as firmas; número de pares a serem coordenados; complexidade das atividades interdependentes; assimetria dos recursos entre os participantes; e custos de transação (flexibilidade para a realização de mudanças).

O viés da análise da negociação enfatiza a forma como o intercâmbio na rede acontece. E o da dependência de recursos traz a subordinação entre os parceiros, moldada por meio da deficiência de recursos, como um elemento-chave para a atuação em rede. As organizações podem desenvolver interdependências complementares ou competitivas. A visão neoinstitucional trabalha também com a ideia da dependência, mas acrescenta o conceito de legitimidade de um recurso, que pode ser entendido como o grau de aceitação de crenças e valores pelas empresas de um grupo (ideias aceitas como verdades).

A corrente centrada nos ideais marxistas foca nas redes constituídas pelo poder, como um impositivo competitivo. A teoria das redes sociais destaca a posição individual das firmas e a importância das estruturas informais de ação. Por fim, o modelo da ecologia populacional realiza estudos que buscam verificar o 
desempenho das empresas que atuam em rede ante as isoladas. A unidade de observação são grupos de empresas com características estruturais semelhantes.

Vale e Lopes (2010, p. 724) empreenderam semelhante esforço por acreditarem que o campo de estudos de cooperação empresarial é, "ao mesmo tempo, rico e diversificado e, também, disperso e desarticulado". Motivados por essa percepção, os autores realizaram um processo de revisão e análise crítica da literatura sobre o tema, que resultou no registro de sete perspectivas teóricas, resumidas no Quadro 2.

\section{QUADRO 2}

\section{PERSPECTIVAS TEÓRICAS SOBRE O ESTUDO DE ALIANÇAS}

\begin{tabular}{|c|c|c|c|}
\hline $\begin{array}{l}\text { PERSPECTIVA } \\
\text { TEÓRICA }\end{array}$ & $\begin{array}{l}\text { ENTENDIMENTO SOBRE } 0 \\
\text { PROCESSO ESTRATÉGICO }\end{array}$ & $\begin{array}{l}\text { ENTENDIMENTO SOBRE } \\
\text { A MOTIVAÇÃO GERAL } \\
\text { DAS ALIANÇAS }\end{array}$ & VISÃO DO AMBIENTE \\
\hline $\begin{array}{l}\text { Teorias } \\
\text { militares }\end{array}$ & $\begin{array}{l}\text { Competir exige } \\
\text { confrontos e coalizões. }\end{array}$ & $\begin{array}{l}\text { Coalizões como forma } \\
\text { de superar limitações } \\
\text { e garantir recursos } \\
\text { estratégicos. }\end{array}$ & $\begin{array}{l}\text { Hostil. Presença de } \\
\text { inimigos e aliados } \\
\text { circunstanciais. }\end{array}$ \\
\hline $\begin{array}{l}\text { Teoria dos } \\
\text { jogos }\end{array}$ & $\begin{array}{l}\text { Interdependência com } \\
\text { os rivais. }\end{array}$ & $\begin{array}{l}\text { Necessidade de } \\
\text { experimentação e } \\
\text { aprendizado mútuo, } \\
\text { evitando dilema dos } \\
\text { prisioneiros. }\end{array}$ & $\begin{array}{l}\text { Competitivo com atores } \\
\text { racionais, capazes de } \\
\text { aprender e otimizar } \\
\text { ganhos. }\end{array}$ \\
\hline $\begin{array}{l}\text { Poder de } \\
\text { mercado }\end{array}$ & $\begin{array}{l}\text { Busca de melhor } \\
\text { posicionamento no } \\
\text { mercado. }\end{array}$ & $\begin{array}{l}\text { Parcerias ao longo da } \\
\text { cadeia produtiva, com } \\
\text { um grupo empresarial } \\
\text { ou agrupamentos } \\
\text { geográficos. }\end{array}$ & $\begin{array}{l}\text { Competitivo e exige } \\
\text { diferenciação. }\end{array}$ \\
\hline $\begin{array}{l}\text { Teoria dos } \\
\text { custos de } \\
\text { transação }\end{array}$ & $\begin{array}{l}\text { Foco nos custos de } \\
\text { transação. }\end{array}$ & $\begin{array}{l}\text { Alternativa para a redução } \\
\text { dos custos de transação. }\end{array}$ & $\begin{array}{l}\text { Instável e turbulento } \\
\text { com empresas } \\
\text { buscando reduzir riscos } \\
\text { e incertezas. }\end{array}$ \\
\hline $\begin{array}{l}\text { Teoria das } \\
\text { redes sociais }\end{array}$ & $\begin{array}{l}\text { Ações resultantes } \\
\text { das interações } \\
\text { entre relações } \\
\text { sociais e interesses } \\
\text { empresariais. }\end{array}$ & $\begin{array}{l}\text { Lado invisível das alianças } \\
\text { estratégicas. }\end{array}$ & $\begin{array}{l}\text { Proliferação de redes } \\
\text { sociais e empresariais. }\end{array}$ \\
\hline
\end{tabular}




\section{QUADRO 2 (CONCLUSÃO)}

PERSPECTIVAS TEÓRICAS SOBRE O ESTUDO DE ALIANÇAS

\begin{tabular}{llll}
\hline $\begin{array}{l}\text { PERSPECTIVA } \\
\text { TEÓRICA }\end{array}$ & $\begin{array}{l}\text { ENTENDIMENTO SOBRE O } \\
\text { PROCESSO ESTRATÉGICO }\end{array}$ & $\begin{array}{l}\text { ENTENDIMENTO SOBRE } \\
\text { A MOTIVAÇÃO GERAL } \\
\text { DAS ALIANÇAS }\end{array}$ & VISÃO DO AMBIENTE \\
\hline $\begin{array}{l}\text { Teoria } \\
\text { baseada em } \\
\text { recursos }\end{array}$ & $\begin{array}{l}\text { Foco em recursos, } \\
\text { habilidades e } \\
\text { capacidades internas. }\end{array}$ & $\begin{array}{l}\text { Possibilidade de renovação } \\
\text { dos recursos empresariais } \\
\text { (capacidades dinâmicas). }\end{array}$ & $\begin{array}{l}\text { Exige alto grau de } \\
\text { diferenciação, sendo a } \\
\text { base para a renovação } \\
\text { de recursos da firma. }\end{array}$ \\
\hline $\begin{array}{l}\text { Teorias do } \\
\text { aprendizado }\end{array}$ & $\begin{array}{l}\text { força indutora da } \\
\text { competitividade } \\
\text { de aprendizado e } \\
\text { mudança. }\end{array}$ & $\begin{array}{l}\text { Meio de } \\
\text { compartilhamento de } \\
\text { conhecimentos. }\end{array}$ & $\begin{array}{l}\text { Competitivo e } \\
\text { dinâmico, exigindo } \\
\text { compartilhamento entre } \\
\text { as empresas. }\end{array}$ \\
\hline
\end{tabular}

Fonte: Adaptado de Vale e Lopes (2010, p. 731).

Balestrin et al. (2010), ao analisarem os trabalhos de Oliver e Ebers (I998) e Brass, Galaskiewicz, Greve e Tsai (2004), elegeram sete correntes teóricas centrais no campo:

- Economia industrial: as redes permitem ganhos econômicos de produção (economia de escala, de escopo e especialização) superiores ao modelo de verticalização.

- Dependência de recursos: as empresas organizam-se em redes para compartilhar ou obter recursos escassos.

- Teoria de redes sociais: acredita que os laços sociais entre os atores da rede influenciam o desempenho da empresa. Busca compreender até que ponto as relações econômicas estão imersas nas relações sociais.

- Teorias críticas: utilizam a noção de poder e controle para entender a dinâmica das relações.

- Teoria institucional: considera a dependência de recursos como aspecto importante, mas seu foco está no entendimento de que a atuação em rede é uma forma de legitimação buscada pela empresa.

- Teoria dos custos de transação: entende que as alianças reduzem os custos de transação entre os envolvidos.

- Abordagem de estratégias organizacionais: compreende que as empresas precisam considerar a habilidade de realizar ações coletivas e de mobilizar recursos como uma premissa para o desempenho, em detrimento da capacidade de competir individualmente. 
Algumas dessas perspectivas podem ser mais facilmente combinadas para compor um referencial analítico para a compreensão de fatos empíricos. É o caso, por exemplo, da teoria baseada em recursos - que pode ser compreendida como um guarda-chuva teórico ${ }^{4}$ que abrange a visão baseada em recursos, as capacidades dinâmicas e as competências essenciais -, da teoria dos custos de transação (TCT), como exemplificaram Cárdenas e Lopes (2006), das teorias do aprendizado - intimamente relacionadas com a teoria baseada em recursos - e da perspectiva poder de mercado (ou economia industrial) (cf. Almeida \& Machado, 2013).

Outras perspectivas são entendidas como concorrentes entre si, como a TCT e as redes sociais. A primeira ampara-se em dois pressupostos: a racionalidade limitada dos envolvidos e o comportamento oportunista, guiado por interesses próprios maliciosos (Cárdenas \& Lopes, 2006; Fagundes, I997; Granovetter, 2007). A TCT advoga que as organizações devem minimizar os custos de transação e enxerga que a opção por realizar uma aliança deve ser feita quando for possível criar uma estrutura de governança que proporcionará uma economia dos custos transacionais (Fagundes, I997).

As redes sociais consideram as decisões humanas imersas em suas relações sociais, ou seja, dependentes do contexto social em que estão, não existindo a possibilidade de uma independência entre uma ação econômica e uma ação social (nesse sentido, não pode haver uma ação puramente econômica), como propuseram Granovetter (2007) e Polanyi (20I2).

Nessa vertente, situam-se autores que compreendem a motivação para a formação e coordenação de alianças como majoritariamente vinculada aos laços sociais, em detrimento da racionalidade econômica, embora ambos não sejam excludentes. Burt (I999) pertence a essa corrente. O autor menciona dois aspectos centrais em uma rede que impulsionam a disseminação da informação: o contágio e o capital social. O primeiro depende de um forte vínculo (coesão) entre o emissor e o receptor da informação, e também da existência de uma estrutura de pensamento similar, resultante de influências conceituais semelhantes (equivalência estrutural). O contágio por coesão influencia o intercâmbio entre os grupos, e o contágio por equivalência, dentro do grupo. O segundo consiste na ideia de que uma ampla rede de contatos tende a melhorar a qualidade das decisões tomadas, a detecção de oportunidades e ameaças.

Outro pesquisador que se empenhou em buscar explicações não somente econômicas para a realização das alianças foi Gulati (I998). O autor notou que as redes sociais estabelecidas, ou seja, os relacionamentos já criados com as empresas,

4 Vale e Lopes (20I0) citam autores que sustentam essa posição. 
não somente influenciavam a criação de novos vínculos, mas também afetavam a configuração, a dinâmica e os resultados das parcerias, sugerindo que os vínculos sociais - por transmitirem (certa) previsibilidade sobre o comportamento dos parceiros - terminam por orientar o comprometimento em alianças numa proporção maior em relação aos pressupostos apoiados nas ideias: de que os indivíduos tomam decisões num cenário de simetria de informação; de que agem com neutralidade diante das relações sociais estabelecidas; e de que se baseiam em planejamentos voltados para a maximização de lucro, redução de custos de oportunismo, entre outros. Gulati (1998) também observou que a familiaridade entre as organizações, conquistada por meio de alianças anteriores, de fato, gera confiança, permitindo às empresas utilizar progressivamente estruturas menos hierárquicas nas novas alianças.

Apreende-se, pois, que a teoria de redes sociais entende as ações econômicas como influenciadas pelo contexto social no qual estão imersas ${ }^{5}$ (embedded) e pela posição do ator na rede de relacionamento. Também considera que as relações sociais das empresas, ao longo dos anos, representam seu capital social. Essa forma de capital pode ser um fator que propicia a formação das alianças, tanto quanto uma consequência dela. Ademais, a estrutura em rede seria um meio de circulação de informação - e, por isso, uma fonte redutora de incerteza -, no qual não somente a identidade dos atores, mas também a natureza dos laços, influencia nas trocas entre os envolvidos. Com relação a este último ponto, Lopes e Baldi (2005) identificaram cinco principais influências dos laços sociais nos arranjos colaborativos: facilitam o fluxo de informações; geram confiança entre os parceiros, o que pode reduzir os custos de transação; representam uma referência para a tomada de decisão; agilizam as transações de mercado, às vezes pulando etapas de negociação; constituem, em algumas culturas, o aspecto-chave para as trocas comerciais.

\section{PRINCIPAIS BENEFÍCIOS DAS ALIANÇAS ORGANIZACIONAIS}

Como visto, tal pluralidade de escolas teóricas demonstra que a motivação geral para a formação das alianças é variada. No entanto, é razoável pensar que existem ganhos de performance $e^{6}$ ou ainda benefícios ou motivadores -, decor-

O sentido de imersão (embeddedness), proposto por Gulati (I998), refere-se ao fato de que as trocas (informações, diálogos etc.) em um grupo possuem uma história, que se desdobra nas rotinas e nos vínculos entre os participantes.

6 Na linguagem de Gulati (I998), falamos aqui da dimensão formação das alianças. Nos termos de Preece (I995), a referência é em relação à dimensão funções. 
rentes da atuação colaborativa, que não são exclusivos de uma abordagem conceitual citada - ou de algumas.

Não faz parte do escopo do artigo realizar um levantamento teórico pormenorizado sobre a descrição de cada uma delas, apontando os principais expoentes que escreveram sobre essas abordagens. Optou-se por examinar a literatura disponível e enumerar os principais benefícios da cooperação interfirmas, tais como: a complementariedade de recursos e o acesso a insumos em prol do aproveitamento de oportunidades de mercado e de sobrevivência; a necessidade de aprendizado, visando suprir déficits de habilidades e adquirir competências; a aprendizagem coletiva; a inovação colaborativa; o compartilhamento de riscos e custos; a criação de estratégias defensivas perante a concorrência ${ }^{7}$; a conquista de legitimidade (quando a inserção na rede sinaliza confiança); o acesso ao capital social; a melhoria da qualidade da relação com os fornecedores; a cooptação de rivais e de firmas complementares; o acesso ao mercado de capitais; a aquisição tecnológica; ganhos econômicos (economia de escala, de escopo, expansão da produção etc.); entre outros (Almeida \& Machado, 20I3; Balestrin \& Verschoore, 2008; Balestrin et al., 20I0; Barney \& Hesterly, 20II; Doz \& Hamel, I998; Gulati, I998; Li et al., 20I3; Pellegrin, Balestro, Antunes, \& Caulliraux, 2007; Preece, I995; Tsang, I998).

Quando se observam os fatores listados, conclui-se que, de modo geral, tais aspectos produzem efeitos em três importantes direcionadores da sobrevivência empresarial: eficiência e poder econômico; diferenciação competitiva perante os concorrentes (obtenção de vantagens competitivas); e flexibilidade gerencial e capacidade adaptativa (entendida como a possibilidade de reverter compromissos assumidos e como a agilidade para explorar oportunidades e evitar ameaças).

Ao final desse levantamento sobre alianças, convém reforçar que o seu objetivo foi apresentar a diversidade de leituras sobre o fenômeno em tela. A opção pela construção de um referencial fundamentado em autores que fizeram um giro conceitual sobre o campo foi a decisão que mais pareceu coerente com o atual estágio da produção científica sobre o objeto empírico em foco: as organizações circenses. Ainda se faz necessário delimitar um escopo analítico propício para o segmento em estudo. Escolher uma perspectiva teórica - como a visão baseada em recursos, capacidades dinâmicas, redes sociais ou qualquer outra anteriormente apontada - implicaria um enquadramento a priori da realidade, o que poderia ser danoso para o amadurecimento da pesquisa - ainda incipiente sobre os modos de organizar circenses. 


\section{O SHOW NÃO PODE PARAR: O ITINERÁRIO METODOLÓGICO}

Esta pesquisa valeu-se da abordagem qualitativa. De acordo com Luz (200I, p. 95), esse tipo de pesquisa "compreende um conjunto de práticas interpretativas, mas não privilegia qualquer tipo de metodologia, inexistindo teoria ou paradigma que lhe seja próprio". Além disso, por se tratar de relações entre seis organizações distintas (três circos e três empresas licenciadoras), concatenadas de diversas formas por meio das narrativas dos sujeitos, considera-se alguma aproximação dos estudos multicasos. Para Triviños (I987), estes consistem na investigação de dois ou mais sujeitos ou objetos por meio da integração e inter-relação de vários estudos de casos.

Os circos em destaque detêm grande estrutura e atuam em cidades de grande porte (maiores de Ioo mil habitantes), circulando em bairros de centros metropolitanos. Todos têm base na família circense, além de contar com elevada aparelhagem estrutural e equipes fixas com dezenas de pessoas. Os espetáculos possuem capacidade de público superior a 500 pessoas e são realizados várias vezes durante a semana. Os circos ouvidos possuem alianças formais efetivadas com licenciadas das marcas: A Turma da Mônica, Galinha Pintadinha e Patati Patatá.

A coleta de informações foi empreendida tendo como fontes as observações assistemáticas, as narrativas dos entrevistados (obtidos por meio de entrevista semiestruturada) e o levantamento documental em sites afins aos interesses da pesquisa.

Dentre os relatos obtidos, foram selecionados aqueles que referenciaram as alianças, os quais dizem respeito a três pessoas envolvidas na área administrativa dos circos e dois artistas. Seus nomes foram transformados em códigos para manter os critérios éticos adotados na pesquisa e serão tratados de (EI) a (E5). De acordo com seus relatos, podem ser caracterizados da seguinte maneira: (E5) é um artista brasileiro, nascido em circo, assim como seus pais. Sua experiência de trabalho no setor é maior que o tempo de vida das unidades circenses pesquisadas. (E4) é funcionário administrativo do circo, mas também irmão do proprietário e conhecedor das alianças formadas pelo seu circo. (E3) esteve um tempo fora do mundo circense, mas, após o falecimento dos pais, retornou e acabou por montar a unidade da qual é proprietária, atuando na sua área administrativa. (E2) é filha do proprietário e atua na parte administrativa, mas também desenvolve o número da "força capilar" ${ }^{8}$ desde os I4 anos. Acompanhou as alianças desde os primórdios do circo, quando este ainda era pequeno (apesar de já usar parcerias).

Número em que a artista fica suspensa a certa altura do palco, com o peso sustentado apenas pelos cabelos. 
Por fim, (EI) é um palhaço chileno, cujos parentes, envolvidos com o circo desde longa data, vieram da Romênia. Compõe a décima geração de palhaços da sua família e está na unidade pesquisada há dois anos, muito embora tenha, assim como (E5), elevado tempo de vida dedicada à atividade circense.

Objetivando uma caracterização histórica das unidades circenses, pode-se dizer que o circo "A" é relativamente novo (aproximadamente oito anos de existência) em relação aos demais, mas com crescimento vertiginoso e estrutura para cerca de 600 pessoas na localidade analisada (mas composto por duas unidades). O circo "B" tem 35 anos (embora tenha mudado de nome durante sua existência) e uma capacidade para até três mil pessoas, apesar de ter começado relativamente pequeno; já o "C", que no momento tem possibilidade de utilizar duas unidades, uma fixa e outra itinerante, também tem mais de 30 anos, além de uma estrutura, na unidade pesquisada, para duas mil pessoas.

As narrativas foram trabalhadas por meio da análise do discurso, que se traduz no uso de um ferramental no qual questões como a seleção do léxico, as figuras e os temas implícitos e explícitos ao texto são consideradas como evidências.

Tema é o elemento semântico que designa um elemento não presente no mundo natural, mas que exerce o papel de categoria ordenadora dos fatos observáveis. São temas, por exemplo, amor, paixão, lealdade, alegria. Figura é o elemento semântico que remete a um elemento do mundo natural: casa, mesa, mulher, rosa etc. A distinção entre ambos é, pois, de maior ou menor grau de concretude (Fiorin, 2005, p. 24).

Nesse sentido, gírias, metáforas, metonímias, ironias, personagens e pressupostos são exemplos de elementos que ajudam a compreender os sentidos que estão sendo transacionados durante a fala: "É a partir do vocabulário que se desenvolvem os demais aspectos linguísticos como personagens e temas, sendo que estes se encadeiam em percursos semânticos" (Faria, 2009, p. 46). Ainda para Faria (2009), esse encadeamento de temas e figuras pode fazer referência a aspectos do mundo mais abstratos ou mais concretos.

Os percursos semânticos se agrupam, por sua vez, no interior de discursos e podem ser considerados como "um conjunto de temas e figuras que materializa uma dada visão de mundo" (Fiorin, 2005, p. 32). Entretanto, uma dada visão de mundo tem relações com outras. Ela se caracteriza também por meio dos interdiscursos com os quais entra em contato: "toda unidade de sentido, qualquer que seja o seu tipo, pode estar inscrita em uma relação essencial com uma outra, aquela do ou dos discursos em relação aos quais o discurso de que ela deriva define sua identidade" (Maingueneau, I997, p. I20). De modo complementar à dimensão interdiscursiva, o discurso se articula também pelo intradiscurso, que 
"se organiza em um conjunto, uma trajetória de sentidos que se desenvolve ao longo do texto" (Faria, 200I, p. 3I). Os discursos, compreendidos como superfície operatória, ajudam, no âmbito desta pesquisa, a trazer informações sobre estrutura, objetivos e funções das parcerias.

\section{TRAZENDO LUZ AO PALCO DAS ALIANÇAS CIRCENSES}

Uma aliança existe sempre que duas ou mais empresas independentes cooperam em determinado negócio, sem que haja perda da identidade das partes (Barney \& Hesterly, 20II). Ficou claro que, nos relacionamentos estudados, preservou-se a autonomia das partes envolvidas. Em termos da estrutura com que tais relações foram desenhadas na prática, poderiam ser vistas como um tipo de acordo de comercialização (Eiriz, 200I; Li et al., 20I3; Tsang, I998); de parceria sem participação acionária (Barney \& Hesterly, 20II); de contrato unilateral (Das \& Teng, 2000); e de arranjos burocráticos e simétricos (Grandori \& Soda, I995).

Constatou-se que as parcerias são um movimento realizado há certo tempo pelos circos com artistas como "Milionário e José Rico, era Mazzaropi [...]" (E2). Entre os resultados alcançados, estava a atração de público: "Então o circo lotava [...]" (E2). Na contemporaneidade, os circos voltaram a utilizar esse tipo de aliança. No entanto, entre a primeira onda de parcerias e o momento atual, há um período em que dois dos circos analisados (B e C) se organizavam com outro tipo de apresentações. Esse período intermediário é distinto, pois “baseava o espetáculo mais nos animais mesmo, né?, poucos números, porque o pessoal só gostava de vim ver o elefante, ver o macaco" (E2). Ao definir uma base maior nos animais, o narrador demonstra um pressuposto: todo o resto tinha uma ênfase menor. Talvez a importância elevada se desse em função de que o público "só gostava" de ver os animais. Essa noção hiperbólica dotada aos animais é ilustrada pelo narrador (E4):

[O०I] Aí antigamente o espetáculo em si não era tão bom, mas o que que trazia o público? Quando não existia isso, o que fazia o público vir para o circo? Era os animais, pra mim os animais era 80\%, o circo não tinha nada, aí traz um elefante, põe na porta do circo e anuncia, enche de gente pra ver o elefante e todo mundo vem dentro do circo pra ver só o elefante. Adora o espetáculo, mas não vê a hora do elefante entrar, porque cê não vê um elefante todo dia na esquina, no zoológico cê vai lá, não é... não tá fazendo... no circo ele tá fazendo alguma coisa, tá plantando uma bananeira [...] (E4). 
No trecho [००I], o sujeito discorre sobre um momento vivido "antigamente". O tempo passado caracteriza um recurso do orador para enfatizar que "não existia isso", o espetáculo "não era tão bom”. Demonstra inferioridade dos números circenses em relação aos do presente. No passado que a narrativa traz à tona, acontece uma separação entre o espetáculo e os animais, com destaque para estes últimos, que eram "80\%". O que existia além parece insignificante, pois "o circo não tinha nada". Tamanho realce chama a atenção para os motivos pelos quais as apresentações com animais eram relevantes: "todo mundo" ia dentro do circo "pra ver só o elefante". Esse animal, que metonimicamente representa o conjunto dos animais, ajuda na manutenção da superioridade hierárquica do seu grupo diante do resto: por mais que o público "adore o espetáculo", "não vê a hora do elefante entrar", pois "não vê um elefante todo dia na esquina", ainda mais "plantando bananeira". No circo, eles vão "fazer algo", o que se contrapõe a certa passividade do animal no zoológico, já que lá ele "não tá fazendo".

Entretanto, essa forma de atrair público para o circo teve fim. Após alguns acidentes e a interferência do poder público, a utilização dos animais foi impedida em grande parte das cidades. Para resumir esses eventos, pode-se afirmar que as organizações passaram "pro circo de bicho, que tem os bichos, animais, elefante, animal, e hoje de novo ao circo tradicional sem animais, cê entendeu?" $\left(E_{5}\right)$. A ausência dessas peças principais deixou uma lacuna no circo, que perdeu um forte estímulo para o público: "Então por aí você vê que pra trazer o povo pro circo tá difícil [...]” (E4). A questão é que

[0०2] [...] o brasileiro tava acostumado com os animais, né? Muito acostumado aos animais. Então eles ia... quando parou os animais no circo, "ah não tem animal, né?”. Então é diferente, eu acho que 70\% do público pensava assim: “O que que o circo vai apresentar agora?" (E5).

A repetição da palavra "acostumado" associada ao vocábulo "muito" reforça a existência de um hábito, algo associado a um costume. Nesse sentido, "eles ia". Entretanto, o hábito é interrompido "quando parou os animais no circo". Mais adiante na narrativa, o entrevistado se faz passar pela personagem coletiva do público, ao simular uma dúvida: "O que que o circo vai apresentar agora?”. Essa pergunta foi prenúncio de uma mudança nas apresentações: “[0०3] [...] quando o público vem ao circo, eles tão adorando, todos os circos têm espetáculo bom. Tem uns que é mais fraco um pouco aqui, mas tem coisa boa, entendeu?" (E4).

Nesse contexto, questiona-se: se o público adora, que sentido teria uma aliança externa? Por meio das entrevistas, notou-se que os circos detêm um conjunto 
de números executados por artistas, geralmente relacionados a uma "família-base", sobre a qual o espetáculo se assenta. Mesmo tendo sido pouco utilizada em momentos anteriores, com maior presença dos animais, o "mastro central" dos espetáculos persiste. Esse alicerce é o que representa, no trecho [005] reproduzido na sequência, "o tradicional": é o que "não pode faltar em circo". Dado o que sempre se mantém, as alianças estratégicas seriam tecidas para complementar o espaço deixado pelo que, ao contrário, não se mantém.

Mas persiste a dúvida: qual lacuna ainda existiria se, como afirma (E4), "todos os circos têm espetáculo bom"? Uma delas pode ser percebida na narrativa do trecho [003]: por mais que o público adore o espetáculo, ele adora "quando vem". Assim, o advérbio "quando" denota uma situação temporal. Significa que o público pode vir ou não. Já que, estando no circo, as pessoas gostarão do espetáculo, às alianças sobrariam outras motivações, que se descortinam por meio das narrativas:

[004] Embora seja um bom espetáculo que possa entrar em qualquer lugar, as pessoas não estão valorizando. Ah, o circo ele tava indo muito fraco, mal tava dando para pagar os funcionários, isso aqui é uma despesa grande. É o tempo todo. Então, o meu filho fez esse contrato com esses palhaços [Patati Patata], para trazer gente $\left(\mathrm{E}_{3}\right)$.

[005] [...] os circos hoje... a maioria dos circos... tem muito circo indo bem, tem a familia, a despesa pequena, ele vai bem, ele sobrevive, uns bons números, trapézio, globo da morte, que é o tradicional, trapézio, globo da morte, malabarista, palhaço, essas coisas não pode faltar em circo. E muitos circos... e tem muitos circos que tão indo mal, que até têm espetáculo bom, assim mais ou meno, mas eu não sei o que acontece com o país, que os circos tão... os circos faz propaganda, faz tudo, cobra barato, e não vai tanta gente. Então hoje em dia os circos que tão indo gente é os circos que têm Patati Patatá, que têm alguma atração fora, de fora entrando no circo, têm nome, é turma da Monica, é Galinha Pintadinha, é Ben ıo, é Backyardigans, todos circos que leva uma atração faz com que o público vá, porque o público vai pra ver aquela atração. Tava adorando o circo, aí cê pergunta: "Por que que eles não vão ver só o circo?". Entendeu? Nós mesmos estávamos com o circo do Patati Patatá, esse ano, tem algumas semanas com o Patati Patatá numa cidade, São Paulo, Bom Sucesso, Guarulhos, que nós anunciamos, lançamos o circo só espetáculo, sem Patati Patatá [...] não foi ninguém, mas ninguém, foi assim horrível. Aí você fala pô... anuncia Patati Patatá, o circo enche (E4). 
Seguindo o percurso semântico9 das motivações das atrações "de fora entrando no circo", o exame dos trechos [004] e [005] gera cinco elementos interdependentes para análise.

O primeiro deles é o fato de que ter além do "que não pode faltar", ou seja, não ter uma "despesa pequena", baseada somente na família, coloca o circo em uma situação de insegurança maior: mesmo tendo um bom espetáculo, trabalhando a publicização do circo e fazendo promoções, a certeza de um bom público inexiste. Nos circos em face, percebe-se que as atrações externas servem "para trazer gente" (E3), pois o "público vai para ver aquela atração" (E4). Segue ainda, na narração do último entrevistado, uma frase afirmativa, quase capaz de antever o resultado da parceria: "todos circos que leva uma atração faz com que o público vá" (E4).

Assim, as alianças são utilizadas como um instrumento para captação de público - e, consequentemente, de receita -, diminuindo, portanto, os riscos comuns à operação de grandes circos, que possuem custos elevados e precisam rentabilizar os seus ativos. Esse achado é compatível com a literatura que aponta a economia de escopo como um possível benefício das alianças, ao mesmo tempo que corrobora a assertiva de Pellegrin et al. (2007) de que as alianças correspondem a uma ação redutora de riscos e incertezas inerentes aos processos inovativos contemporâneos. Essa redução de incerteza por meio das alianças parece ser uma prática comum aos circos - ou a um grupo específico deles -, dado que as atrações externas eram utilizadas antes dos números com animais:

[006] Olha, eu me lembro, o circo era pequeno, que eu me lembro por gente assim, eu fazia números [como] escada de garrafa, que é circo... é número pra circo pequeno mesmo. E aí foi... eu lembro que meu pai foi dando sorte nas cidades e o circo começou a ir muito bem. Na época trazia show, era Milionário e José Rico, era Mazzaropi. Então o circo lotava, então é... (E2).

Um segundo elemento de destaque é a compreensão do objeto circo. Parece haver, pelo menos, dois principais arranjos circences. Um baseado na família, no espetáculo tradicional, cuja estrutura de custos é menor. Outro que mantém a base familiar, isto é, que preserva o espetáculo tradicional, mas cuja receita supõe-se advir, em grande medida, das atrações externas. Essas são afirmações provisórias, pois o estudo em questão possui um alcance limitado em relação ao universo investigado. Tal observação, no entanto, abre espaço para um promissor tema de pesquisa sobre os diversos modos de existência circenses.

9 Considerado, por meio da perspectiva de Faria (2009), o encadeamento de aspectos linguísticos, como personagens e temas. 
O terceiro elemento refere-se à constituição das identidades que formam o que se denomina circo, como se ele fosse um todo homogêneo. As atrações externas não fazem parte do espetáculo, pois existe uma separação entre o "espetáculo" e o "de fora". Essa conclusão é respaldada por um jogo entre tempo passado e presente. Quando se lançou (passado) o circo somente com "o espetáculo”, “não foi ninguém, mas ninguém, foi assim horrível” (E4). Dessa maneira, quando se “anuncia Patati Patatá, o circo enche" (presente). Esse é um fato empírico relevante para acadêmicos em administração que se ocupam em estudar a fluidez e a extensão dos limites organizacionais e as consequências desse debate sobre a cognição dos pesquisadores e o desenho das pesquisas na área.

Outro elemento diz respeito à importância de recursos e expertise externos, absorvidos por meio das alianças, para a sobrevivência dos circos. A escola da teoria da dependência de recursos entende esse fato como o motivador central para a realização de acordos de cooperação. Mas é necessário, a partir dessa perspectiva, problematizar essa dependência, perguntando: qual é o grau de subordinação dos circos em relação a esses agentes externos? Qual é a dependência das marcas Patati Patatá, Galinha Pintadinha e Turma da Mônica em relação aos circos? A Turma da Mônica, por exemplo, possui um espetáculo de circo chamado Turma da Mônica no mundo do circo. Se essa for uma tendência nesse segmento, o quanto essa prática afetará a sobrevivência dos circos de maior porte?

O quinto elemento - intimamente ligado aos dois últimos - diz respeito à reputação das alianças. Sem as atrações de "fora do circo", fica-se sem compreender "por que eles não vão ver só o circo" (o pronome "eles" se refere ao público). Tal constatação abre campo para explorar a legitimidade dos parceiros como um antecedente para as alianças, seguindo o legado institucionalista.

De modo geral, os trechos de [oor] a [0०6] fornecem evidências da necessidade de complementar o espetáculo (visto como o conjunto dos números tradicionais) por meio das parcerias. Um dos recursos ampliados refere-se à capilaridade geográfica das organizações circenses. Como se percebe no trecho [0०7], determinado circo que circulava pela Região Sudeste pôde itinerar com uma nova lona por outra região:

[007] no começo do ano a gente fez um... uma parceria com Patati Patatá e eu e meu irmão fomos pra outra... essa outra lona pra Santa Catarina. Então a gente fez todo o Estado de Santa Catarina com o Patati Patatá. E aí meu pai ficou nessa unidade com a esposa dele tomando conta. Aí acabou lá a sociedade, acabou a parceria, a gente juntou de novo. É assim, surge alguma coisa, a gente sai (E2). 
No caso, uma unidade se transformou em duas. A divisão, devido a uma possibilidade de rota diferente, em "outra lona" (que metonimicamente representa outro circo, com artistas, e mais questões estruturais) permitiu, como elucida a metáfora "fez todo o Estado", que a parceria percorresse grande parte do Estado de Santa Catarina com o Patati Patatá.

A frase "Aí acabou lá a sociedade, acabou a parceria, a gente juntou de novo" sugere que os acordos interfirmas são uma importante iniciativa para buscar flexibilidade gerencial, conferindo às organizações circenses uma capacidade adaptativa diante de seu contexto de atuação, de sua necessidade momentânea e das oportunidades do mercado. Esse senso de oportunismo pode ser interpretado, à luz da abordagem de estratégias organizacionais sugerida por Balestrin et al. (20I0), como uma habilidade de realizar ações coletivas e de mobilizar recursos, em detrimento da capacidade de competir individualmente.

Outro motivador relevante para a formação das parcerias examinadas neste artigo foi a possibilidade de reforço de posicionamento num mercado de nicho (segmento familiar), como mencionado pela perspectiva "poder de mercado", categorizada por Vale e Lopes (20I0). Quando perguntou-se, nas entrevistas realizadas, quem ia ao circo, percebeu-se que os frequentadores são

[0o8] Só família[s], acho que é metade criança e metade, porque vêm o pai e mãe e dois filhos, três filhos, criança tem muita, porque, por causa do show de Patati Patatá, porque esses palhaços estão na moda agora e pessoal fica enlouquecida, as crianças, né?, aí tem que vir, o pai, a mãe ou avó, então são famílias, exclusivamente familias (E3).

A metáfora das crianças "enlouquecidas" demonstra que os palhaços que "estão na moda" possuem um potencial mercadológico. Ao lançar mão das parcerias, o circo se posiciona diferenciadamente, pois traz um parceiro reconhecido nacionalmente. Os parceiros gozam de reputação junto ao público, fomentada por meio de visitas feitas em escolas, bem como pela exposição na mídia nacional por meio de programas televisivos, no caso do Patati Patatá (Jakitas, 20I2) e da Turma da Mônica. Esse último parceiro dispõe de revistas em quadrinhos, centenas de produtos licenciados que utilizam os personagens e diversas ações de marketing, como a comemoração do aniversário da personagem Mônica: ação relativamente divulgada desde a imprensa nacional até carnaval em Salvador (Galeano, 20I3; Rocha, 2013). Com relação à Galinha Pintadinha, sua forma principal de comunicação (mas que extrapolou o meio digital atualmente) são os vídeos na internet. Com mais de 600 milhões de visualizações, a Galinha Pintadinha 
[...] é um verdadeiro império de vendas. Na temporada de Natal, a galinha de pelúcia foi o segundo brinquedo mais vendido nas I24 lojas da rede Ri Happy no país. Em pouco mais de um ano, passou de cem para mais de 400 produtos licenciados, entre brinquedos, material escolar e produtos de higiene pessoal. [...] analistas de varejo estimam o faturamento da Bromélia [produtora que administra a marca], com apenas sete funcionários, em dezenas de milhões de reais por ano (Gazeta do Povo, 2013).

Essa presença em veículos midiáticos diversos é algo que, mesmo sendo encontrado no caso dos circos, não acontece com a mesma intensidade. Esse cenário justifica a associação do circo com esses parceiros, lembrando que a relação pode impor o desafio da dependência. O circo se aproxima dos seus parceiros, embora as relações apresentem um distanciamento. A narrativa de certo palhaço circense serve de exemplo para essa "aproximação à distância":

[009] Não, primeiro nós. Depois Patati. [...] E ele faz... segura a segunda parte. Só que não atinge nada pra nós porque ele é só um palhaço é montado. [...] Ele é só montado. Ele leva uma rotina. Ele faz só aquela comédia que... comédia, como se fala, só o esquete do CD rolado. Se você colocar ele pra fazer o que nós faz, ele se perde. [...] a gente tenta agradar, se vê que não tá, vamo trabalhar mais rápido, entendeu, pra não virar cansativo pro público. Então cê tem que trabalhar com a malícia, se tá agradando, cê vai empurrando (EI).

[ого] Acho que a diferença é muito grande. E você vê que é bem diferente, muito diferente, o modo de cumprimentar, o modo de andar na pista. [...] É. Pode prestar atenção, são bem diferentes. A gente prefere fazer coisas mais simples, não tão simples também, nós temos trabalho [...]. Mas ocê olhar pra cara do povo, e o povo entrar no que você tá fazendo (E5).

Os fatos empíricos levantados pela pesquisa também sugerem que há espaço para investigação dos antecedentes da formação das alianças, sob a ótica da teoria das redes sociais. Uma das possibilidades de pesquisa nessa linha é verificar a lógica utilizada nas escolhas dos parceiros. Em relação às unidades pesquisadas, constatou-se que as redes sociais estabelecidas, ou seja, os relacionamentos já criados com as empresas e indivíduos, parecem influenciar novos vínculos. Em um dos casos analisados, tornou-se evidente a existência de conexões anteriores entre uma licenciada e o mundo circense. Simplesmente 
“o Patati Patatá ele vem, é como ele já conhece, ele já trabalhava em circo Rinaldi, que é o dono [...]” (E2). Fazendo uma análise do interdiscurso existente no site da dupla, descobriu-se que o mágico Rinaldi já conhecia a realidade circense antes de adquirir os direitos da marca Patati Patatá (Patati Patatá, 2013), o que é reafirmado por (E2) quando diz que "ele já conhece”. Afinal, "ele já trabalhava em circo".

Patati e Patatá são dois palhaços com raízes no circo. Seguindo o conceito de equivalência estrutural de Burt (I999), é razoável pensar que existe entre ambos os palhaços e os circos uma afinidade simbólica, resultante de influências conceituais semelhantes, sincretizadas pela figura cômica: o palhaço. Também é possível que haja uma aproximação entre Rinaldi e os circos ouvidos, pois o próprio mágico atuava em espetáculos circenses. O quanto esses laços facilitam a negociação comercial e a troca de informações, e reduzem os custos transacionais? Essas são proposições cabíveis para uma futura pesquisa. Também é pertinente analisar a possibilidade de o capital social envolvido direcionar a escolha dos agentes com os quais os circos estabelecerão parcerias. Afinal, se a decisão dos circos entrevistados fosse estritamente econômica - por exemplo, se a escolha fosse motivada unicamente com o objetivo de rentabilizar seus ativos fixos e diminuir a incerteza de receita -, o circo poderia abrir espaço para shows diversos ou mesmo repensar completamente seu posicionamento, ampliando as alternativas de reinvenção do negócio.

À luz do legado da teoria dos custos de transação (TCT), é interessante explorar, como foco de estudo, as relações contratuais entre os protagonistas das parcerias analisadas ${ }^{\mathrm{IO}}$. Pouco se sabe sobre o equilíbrio informacional entre as partes, a divisão de responsabilidades e de receitas, sobre instrumentos de proteção intelectual, entre outras variáveis envolvidas. Nas entrevistas, pôde-se perceber - para citar um exemplo de variável relevante para o estudo das relações contratuais - uma diferenciação na composição dos custos da divulgação. Um dos respondentes sustenta que não há necessidade de se empenhar na publicidade "da Galinha Pintadinha [...] porque eles têm uma equipe de divulgação, [...] agora do Patati Patatá sim" (E2). A empresa que tem os direitos da marca Patati Patatá utiliza a estrutura dos circos para publicidade dos espetáculos. Já no caso da outra marca, quem arca com os custos é a detentora dos direitos da Galinha Pintadinha. A divulgação ainda impõe restrições aos circos, como se observa no trecho [OII]:

ro À semelhança da pesquisa de Batista, P. C. S., Paiva, T. A., Ramos, R. R., Almeida, P. C. H., \& Oliveira, L. G. L. (20II), que investigaram as relações contratuais na indústria dos quadrinhos (HQs) no Ceará. 
[OII] Não tem espetáculo hoje, devido a esse show dos palhaços na televisão. Eles só vêm sexta, sábado, domingo e feriado. Alguns dias da semana, eles não vêm, então a gente não pode funcionar o circo, porque a propaganda tá com eles. Então a gente não pode dá espetáculo, porque as pessoas vão vir e vão falar cadê os palhaços, então, para não dá confusão, a gente prefere não dá espetáculo. Mas, quando é normal mesmo, quanto é espetáculo normal do circo não. Só tem a folga né?, a folga do pessoal na segunda-feira, e terça, quarta até domingo é espetáculo (E3).

Por existirem outros compromissos dos palhaços, o circo "não pode dá espetáculo”, para não incorrer em propaganda enganosa. "Para não dá confusão”, a organização perde dois dias de espetáculos, pois a "propaganda tá com eles”. Existem, assim, algumas restrições ao funcionamento dos circos, oriundas de outras prioridades das contratadas/licenciadas. A atração externa, que proporciona uma série de vantagens mencionadas neste artigo, traz consigo limitações ao funcionamento dos circos. Existem outras interferências impostas pelos parceiros que já conheciam o mundo circense, como o preço a ser cobrado nas bilheterias.

[ол2] Da Galinha Pintadinha, a gente manteve o preço, que eles num... agora do Patati eles exi... exigiram, né?... que eles têm um mínimo, 40 e 20 os ingressos deles, porque eles num... pra não ter esse negócio, ah, se uma cidade foi um preço, outra cidade foi outro. Então eles tipo... eles estipula um preço em todos os shows de circo (E2).

A mobilidade geográfica dos circos gera uma demanda pela alteração de preços, pois, em certas praças, pode haver a necessidade de promoções, como fica claro no trecho [005]. Entretanto, essa flexibilidade torna-se restrita quando se lança mão do espetáculo dos palhaços, que "exigiram" a manutenção do padrão de preços em todas as cidades. Ao final do trecho, o pronome "eles" remete novamente ao nome dos artistas. A "eles" cabe estipular "um preço". Mas não qualquer preço, pois "eles têm um mínimo" para "todos os shows de circo". Cabe ressaltar que a determinação do preço por uma das partes da aliança gera uma assimetria transacional, revelando, num nível micro, a existência de jogos de poder nas relações interorganizacionais, enfoque adotado pela escola crítica, vertente teórica que, segundo Balestrin et al. (2010), estuda a dinâmica evolutiva das redes pelo viés do poder e controle. Tal perspectiva é pouco explorada na produção nacional sobre o tema. Normalmente, o poder é visto como um conceito negativo, contrário à própria noção de cooperação (Giglio, Pugliese, \& Silva, 20I2). Necessário se faz caminhar na ampliação do conceito de poder, incorporando-o como uma variável explicativa da formação, coordenação e dinâmica das alianças. 
Desse modo, o exame dessa situação sugere que a parceria pode levar a uma restrição do potencial competitivo do circo, uma vez que sua possibilidade de adequação do preço à cidade visitada ou a outros fatores circunstanciais fica limitada. Ocorre assim, um paradoxo: a aliança promove o desempenho do circo, ao mesmo tempo que pode gerar perda de competitividade. A promessa de flexibilidade, presente quase na totalidade das correntes conceituais sobre alianças estratégicas como um ganho obtido naturalmente por meio da participação em parcerias, deve, a todo momento, passar pelo crivo crítico das pesquisas de campo.

Outra variável de análise pertencente ao escopo da TCT é a divisão entre despesas e faturamento. Constatou-se que essa partilha é a mesma para todos os pesquisados: o faturamento "é 50\% dele, $50 \%$ do circo" (E2). Entretanto, por mais que "a metade da renda vai para eles, limpinho [...]" (E3), as despesas são, em maior parte, do circo. Ou seja, o circo tem à sua disposição a metade do faturamento que "fica para gente pagar tudo, terreno, água, luz. [...] a despesa toda é do circo, carro de som, do carro de som até o quilo de feijão. Eles não arcam com nenhuma despesa, a não ser a deles mesmos" (E3).

\section{FECHANDO AS CORTINAS: CONSIDERAÇÕES FINAIS E SUGESTÕES}

O objetivo do presente artigo foi estudar a contribuição das alianças para a longevidade das empresas, tendo como objeto empírico as organizações circenses. Dentro desse escopo, buscou-se responder em que medida as unidades pesquisadas realizaram alianças - com os personagens infantis Patati Patatá, Galinha Pintadinha e Turma da Mônica - capazes de gerar benefícios competitivos e fortalecer o seu posicionamento. A literatura investigada aponta que as alianças são uma fonte de valor por permitirem às empresas usufruir de benefícios que maximizam a competitividade. Os casos estudados comprovaram a apropriação de alguns desses benefícios. Chegou-se à conclusão de que as parcerias proporcionaram ganhos de performance nas dimensões:

- Econômica: as parcerias são utilizadas pelos circos para reduzir incerteza de público, estabilizar o fluxo de receita e maximizar os seus ativos.

- Diferenciação competitiva: conquistada por meio da partilha de recursos entre as partes, tais como: legitimidade, capital simbólico (denotando a representatividade do imaginário circense no público), capital social e ativos físicos (especialmente da parte dos circos). Essa partilha permite aos circos a consolidação do seu posicionamento no segmento de consumo familiar. 
- Desenvolvimento de capacidade adaptativa: as parcerias examinadas sugerem que os circos possuem um senso de oportunismo, descrito como uma capacidade de explorar oportunidades de mercado imediatas. As alianças revelaram um meio de expansão territorial, constituindo-se numa forma dinâmica de entrar e sair de mercados.

Outro achado relevante diz respeito à presença das alianças no cotidiano dos circos. Constatou-se que as parcerias vêm de longa data e podem ser divididas em duas fases, que atendem a demandas históricas específicas. Houve um primeiro momento em que as alianças com artistas populares, inseridos no mundo musical e cômico, atraíam o público. No período seguinte, os números com animais - os próprios circos eram proprietários deles - ocuparam esse lugar. Nas narrativas dos entrevistados, o espetáculo tradicional (uma referência ao núcleo artístico base do circo) não era tão bom, e a popularidade era decorrente dos animais, pois representavam algo incomum: não eram vistos todos os dias e, além disso, faziam coisas diferentes, eram mais ativos que em um zoológico. Assim, sua capacidade em atrair a audiência era elevada. O fim dessa possibilidade, devido à proibição imputada por diversas leis municipais, criou um espaço vazio no circo, ocupado pela parceria com as licenciadas contemporâneas: Patati Patatá, Galinha Pintadinha e Turma da Mônica. Essa última fase representa um retorno à primeira, dado que, em ambas, as atrações externas ("fora do circo") foram a opção encontrada pelos estrategistas circenses para conquistar espectadores.

Essa constatação, provisória em função dos limites quanto à generalização dos resultados deste estudo, sugere que a disposição para a realização de alianças está presente na cultura do circo, ou seja, faz parte das relações de produção econômicas e sociais em torno da prática circense. As alianças ocupam o repertório de práticas dos empreendedores circenses desde a década de i970, o que parece facilitar os processos de mudança demandados pela sociedade atual. $\mathrm{O}$ conceito de path dependencies ${ }^{\text {II }}$ parece ser especialmente adequado para, num esforço acadêmico posterior, examinar essa situação empírica detectada, em que a aliança representa uma capacidade adaptativa, que possui raízes no passado organizacional.

É importante lembrar que o objetivo secundário deste trabalho foi gerar subsídios para pesquisas acerca do circo. Pretende-se, aqui, propor objetos de

Path dependencies (trajetória histórica ou evolucionária) é um conceito presente no arcabouço da teoria das capacidades dinâmicas. Afirma que as alternativas estratégicas disponíveis para uma empresa dependem de sua condição atual (de seu estoque de recursos e processos), mas também dos caminhos já percorridos. Esse conceito problematiza a noção da microeconomia de agente econômico racional, capaz de avaliar as informações disponíveis e escolher a opção ótima, por exemplo, na seleção de fornecedores, compra de tecnologias etc.; ao mesmo tempo, valoriza a noção de aprendizagem como um processo de experimentação, feedback e avaliação (Teece, Pisano, \& Shuen, I997). 
investigação, mais do que resolver um problema ou dar uma resposta definitiva. Por tal motivo, o referencial teórico foi elaborado em uma perspectiva ampla, a fim de se constituir como base conceitual a partir da qual fosse possível sinalizar oportunidades de pesquisas - posição coerente com o estágio incipiente da pesquisa no segmento em tela. Assim, a análise do artigo buscou responder à questão central do trabalho, ao mesmo tempo que enumerou sugestões para iniciativas subsequentes. Por conseguinte, numerosos caminhos foram apontados, tais como investigações sobre: I. os múltiplos modos de existência circenses; 2. a fluidez e extensão dos limites organizacionais, a partir da constituição da identidade circense, formada por uma cisão entre o núcleo-base familiar e o "de fora”; 3. a relação de subordinação e os jogos de poder entre as partes envolvidas, com destaque para o exame da ambivalência gerada pelas alianças, expressa pelo paradoxo da conquista de flexibilidade versus a restrição competitiva; 4. a influência dos laços sociais na escolha e na coordenação das alianças; 5 . as relações contratuais na indústria circense; 6. o aprofundamento da identificação dos recursos compartilhados.

Por fim, cabe pontuar que as constatações desta pesquisa não podem ser generalizadas, dado o recorte da população investigada. Espera-se, pois, que seus achados representem um estímulo para a continuidade dos esforços acadêmicos nessa direção.

\section{STRATEGIC ALLIANCES IN THE ARENA OF ART/CIRCUS BUSINESS}

\section{ABSTRACT}

The objective of this paper is to study the alliances contribution for companies longevity, having as object a field almost forgotten by management, the circus organizations. Despite the economic and symbolic importance, the sector is poorly studied from a view point of their management practices. In this sense, the problem proposed is to identify the extent to which the researched organizations realize alliances that generate competitive benefits. The research focus is partnerships with licensed brand icons of the Brazilian children's entertainment, as Patati Patatá, Lottie Dottie Chicken and Monica's Gang. A secondary objective sought to generate suggestions for future research on the circus, reason why the theoretical framework on organizational alliances was prepared in a broad perspective, consistent with the early stage of scientific production at segment. Methodologically, a qualitative approach was adopted, based on interviews 
in three Southeast Brazilian large circuses. Information was worked through discourse analysis. The case studies showed that alliances are a source of value for providing performance gains in the economic, competitive differentiation, and development of adaptive capacity, denoted by an opportunism sense, emerged from partnerships. Another important finding concerns the presence of old alliances in everyday circuses. Paths for future academic efforts were also mentioned on: I. organizational existence modes of circus; 2. organizational boundaries fluidity and extent; 3. subordination relationship and power games between the involved parties, with emphasis on ambivalence generated by alliances, expressed by the paradox of flexibility conquest versus competitive constraint; 4 . social ties influence both in alliances selection and in their coordination; 5. contractual relations in circus industry; 6 . a depth identification of shared resources. Finally, it's required to point out that findings raised can not be generalized, due to the investigated population cut.

\section{KEYWORDS}

Strategic aliances. Circuses. Partnerships. Circus organizations. Family entertainment.

\section{ALIANZAS ESTRATÉGICAS EN LA PISTA DEL ARTE/NEGOCIO CIRCENSE}

\section{RESUMEN}

El objetivo del artículo es estudiar la contribución de las alianzas para la longevidad de las empresas, teniendo como objeto un campo casi olvidado por la administración, las organizaciones circenses. A pesar de su importancia económica y simbólica, este sector es poco estudiado desde el punto de vista de sus prácticas de gestión. En este sentido, el problema propuesto para examen es identificar en qué medida las unidades investigadas realizan alianzas que generen beneficios competitivos. La investigación se centra en las asociaciones hechas con marcas relevantes del entretenimiento infantil nacional, como Patati Patatá, Mónica y su Pandilla y Gallina Pintadita. Como objetivo secundario, se pretende generar sugerencias para futuras investigaciones acerca del circo, razón por la cual el referencial teórico sobre las alianzas organizacionales ha sido elaborado en una perspectiva amplia, posición coherente con la etapa incipiente de la producción 
científica en el segmento. Metodológicamente, se ha adoptado un abordaje cualitativo, basándose en entrevistas en tres grandes circos de la Región Sudeste de Brasil. Las informaciones han sido trabajadas a través del análisis del discurso. Los casos estudiados han mostrado que las alianzas son una fuente de valor por proporcionar ganancias de desempeño en las dimensiones: económica (la reducción de riesgos, la maximización de los activos y los ingresos); de diferenciación competitiva (resultante de la partición de recursos); y de desarrollo de la capacidad adaptativa, que se denota por el sentido de oportunismo derivado de las asociaciones. Otro hallazgo relevante se refiere a la antigua presencia de las alianzas en el cotidiano de los circos. También han sido apuntados caminos para esfuerzos académicos posteriores sobre: I. los modos de existencia de las organizaciones circenses; 2 . la fluidez y extensión de los limites organizacionales; 3. la relación de subordinación y los juegos de poder entre las partes implicadas, especialmente el examen de la ambivalencia producida por las alianzas, expresa por la paradoja de la conquista de la flexibilidad versus la restricción competitiva; 4. la influencia de los lazos sociales en la elección y en la coordinación de las alianzas; 5. las relaciones contractuales en la industria circense; 6 . la profundización de la identificación de los recursos compartidos. Por último, se señala que las constataciones detectadas no pueden generalizarse, dado el recorte de la población investigada.

\section{palabras clave}

Alianzas estratégicas. Circos. Asociaciones. Organizaciones circenses. Entretenimiento familiar.

\section{REFERÊNCIAS}

Almeida, L. F., \& Machado, C. A. P., Filho (2013). Sharing competences in strategic: alliances: a case study of the Cosan and Shell biofuel venture. Revista de Administração, 48(2), 359-374.

Balbinot, Z., \& Marques, R. A. (2009). Alianças estratégicas como condicionantes do desenvolvimento da capacidade tecnológica: o caso de cinco empresas do setor eletro-eletrônico brasileiro. RAC-Revista de Administração Contemporânea, 13(4), 604-625.

Balestrin, A., \& Verschoore, J. (2008). Redes de cooperação empresarial: estratégias de gestão na nova economia. Porto Alegre: Bookman.

Balestrin, A., Verschoore, J. R., \& Reyes, E., Junior (20IO). O campo de estudo sobre redes de cooperação interorganizacional no Brasil. RAC-Revista de Administração Contemporânea, 14(3), 458-477. Barney, J. B., \& Hesterly, W. S. (20II). Administração estratégica e vantagem competitiva (3a ed.). São Paulo: Pearson Prentice Hall. 
Batista, P. C. S., Paiva, T. A., Ramos, R. R., Almeida, P. C. H., \& Oliveira, L. G. L. (2OII). As relações contratuais das indústrias criativas: o caso dos quadrinhos no Ceará. Cadernos Ebape.BR, 9(2), 377-393. Brass, D., Galaskiewicz, J., Greve, H., \& Tsai, W. (2004). Taking stock of networks and organizations: a multilevel perspective. Academy of Management Journal, 47(6), 795-8I7.

Burt, R. (I999). The social capital of opinion leaders. The ANNALS of the American Academy of Political and Social Sciente, 566(I), 37-54.

Cárdenas, L. Q., \& Lopes, F. D. (2006). A formação de alianças estratégicas: uma análise teórica a partir da teoria da dependência de recursos e da teoria dos custos de transação. Cadernos Ebape. $B R, 4(2), \mathrm{I}-8$.

Carrão, A. M. R. (2004). Cooperação entre empresas de pequeno porte em polos industriais: um estudo comparativo. Revista de Administração, 39(2), I86-I95.

Castro, M., Bulgacov, S., \& Hoffmann, V. E. (20II). Relacionamentos interorganizacionais e resultados: estudo em uma rede de cooperação horizontal da região central do Paraná. RAC - Revista de Administração Contemporânea, 15(I), 25-46.

Das, T. K., \& Teng, B.-S. (2000). A resource-based theory of strategic alliances. Journal of Management, 26(I), 3I-57.

Doz, Y. L., \& Hamel, G. (I998). Alliance advantage: the art of creating value through partnering. Boston: Harvard Business School Press.

Eiriz, V. (200I). Proposta de tipologia sobre alianças estratégicas. RAC-Revista de Administração Contemporânea, 5(2), 65-90.

Estivalete, V., Pedrozo, E., \& Begnis, H. (2008). Em busca da ação coletiva: estratégias de aprendizagem interorganizacional adotadas pelas organizações que estabelecem relacionamentos horizontais em redes. Base - Revista de Administração e Contabilidade da Unisinos, 5(3), 224-235.

Fagundes, J. (I997). Economia institucional: custos de transação e impactos sobre política de defesa da concorrência [Texto para discussão, $n^{\circ}$ 407]. Rio de Janeiro: IE/UFRJ.

Faria, A. A. M. de. (200I). Interdiscurso e intradiscurso: da teoria à metodologia. In E. A. Mendes, P. M. Oliveira \& V. Benn-Ibler (Orgs.). O novo milênio: interfaces linguísticas e literárias. Belo Horizonte: Fale/UFMG.

Faria, A. A. M. de (2009). Aspectos de um discurso empresarial. In A. P. Carrieri, L. A. S. Saraiva, T. D. Pimentel \& P. A. G. Souza-Ricardo. Estudos organizacionais e análise do discurso: aproximações possiveis. Curitiba: Juruá.

Fiorin, J. L. Linguagem e ideologia (8a ed.). São Paulo: Ática, 2005.

Galeano, M. (20I3). Mônica chega ao $50^{\circ}$ aniversário, ganha bolo de verdade e festa o ano inteiro. Folha de S.Paulo. Recuperado em 4 setembro, 20I3, de http://wwwi.folha.uol.com.br/folhinha/I237II3-monica-chega-ao-50-aniversario-ganha-bolo-de-verdade-e-festa-o-ano-inteiro.shtml.

Gazeta do Povo. O império da Galinha Pintadinha. 2013. Recuperado em 6 setembro, 2013, de http://www.gazetadopovo.com.br/economia/conteudo.phtml?id=I345694\&tit=O-imperio-da-Galinha-Pintadinha.

Giglio, E., Pugliese, R. L., \& Silva, R. M. (20I2). Análise dos conceitos de poder nos artigos brasileiros sobre redes. Revista de Administração da Unimep, 10(3), 5I-69.

Grandori, A., \& Soda, G. (I995). Inter-firm networks: antecedents, mechanisms and forms. Organization Studies, 16(2), I83-214. 
Granovetter, M. (2007). Ação econômica e estrutura social: o problema da imersão. RAE eletrônica Revista de Administração de Empresas, 6(I).

Gulati, R. (I998, April). Alliances and networks. Strategic Management Journal, 19(4), 293-3I7.

Jakitas, R. (20I2). Personagens brasileiros turbinam o mercado de licenciamentos. Recuperado em 6 setembro, 20I3, de http://pme.estadao.com.br/noticias/noticias,-personagens-brasileiros-turbinam-o-mercado-de-licenciamentos,216I,o.htm.

Kirschbaum, C. (2006). Renascença da indústria brasileira de filmes: destinos entrelaçados? RAE Revista de Administração de Empresas, 46(3), 58-71.

Laimer, C. G., \& Laimer, V. R. (2009). Relações de cooperação na perspectiva da visão baseada em recursos. Revista de Administração da Unimep, 7(3), 93-IIo.

Li, L., Qian, G., \& Qian, Z. (20I3). Do partners in international strategic alliances share resources, costs, and risks? Journal of Business Research, 66, 489-498.

Lopes, F. D., \& Baldi, M. (2005). Laços sociais e formação de arranjos organizacionais cooperativos proposição de um modelo de análise. RAC-Revista de Administração Contemporânea, 9(2), 8I-IOI. Luz, T. R. (200I). Telemar-Mimas: competências que marcam a diferença. Tese de doutorado em Administração, Universidade Federal de Minas Gerais, Belo Horizonte, MG, Brasil.

Magnani, J. G. C. (2003). Festa no pedaço: cultura popular e lazer na cidade. São Paulo: Editora Unesp, Hucitec.

Maingueneau, D. (1997). Novas tendências em análise do discurso. Campinas: Pontes.

Oliveira, A. L., Rezende, D. C., \& Carvalho, C. C. (20II). Redes interorganizacionais horizontais vistas como sistemas adaptativos complexos coevolutivos: o caso de uma rede de supermercados. $R A C-$ Revista de Administração Contemporânea, 15(I), 67-83.

Oliver, A. L., \& Ebers, M. (I998). Networking network studies: an analysis of conceptual configurations in the study of inter-organizational relationships. Organization Studies, 19(4), 549-583.

Patati Patatá. Institucional: uma história de muito amor e alegria. Recuperado em iI setembro, 20I3, de http://www.patatipatata.com.br/nossa-historia.php.

Pellegrin, I., Balestro, M. V., Antunes, J. A. V. A., Junior, \& Caulliraux, H. M. (2007). Redes de inovação: construção e gestão da cooperação pró-inovação. Revista de Administração da Universidade de São Paulo, 42(3), 313-325.

Pereira, P. S., Neto, \& Marujo, E. C. (2OII). Alianças de companhias aéreas: vantagens permanentes? Revista de Administração, 46(I), 87-Io0.

Polanyi, K. (20I2). A grande transformação. Rio de Janeiro: Elsevier.

Preece, S. B. (I995). Incorporating international strategic alliances into overall firm strategy: a typology of six managerial objectives. The International Executive, 37(3), 26I-277.

Reis, A. C. F. (2007). Economia da cultura e desenvolvimento sustentável: o caleidoscópio da cultura. Barueri: Manole.

Rocha, R. Mônica mais forte que nunca. Meio\&Mensagem, 20I3. Recuperado em 6 setembro, 20I3, de http://www.meioemensagem.com.br/home/marketing/noticias/2013/02/26/Monica-mais-forte-que-nunca.html.

Rossi, G. B., \& Póvoa, A. (2008). Alianças estratégicas em empresas de médio porte: um estudo no setor de automação industrial automobilística no Brasil. Base - Revista de Administração e Contabilidade da Unisinos, 5(3), I98-212. 
Silva, E. R., Lopes, D. P. T., \& Muniz, R. M. (2013). O modelo produtivo cinematográfico brasileiro: dimensionando a importância das alianças entre os atores do campo. Anais do Encontro da Associação Nacional de Pós-Graduação e Pesquisa em Administração, Rio de Janeiro, RJ, Brasil, 37.

Teece, D. J., Pisano, G., \& Shuen, A. (I997). Dynamic capabilities and strategic management. Strategic Management Journal, 18(7), 509-533.

Triviños, A. R. S. (I987). Introdução à pesquisa em ciências sociais: pesquisa qualitativa em educação. São Paulo: Atlas.

Tsang, E. W. K. (1998). Motives for strategic alliance: a resource-based perspective. Scandinavian Journal of Management, 14(3), 207-22I.

Vale, G. M. V., \& Lopes, H. E. G. (20I0). Cooperação e alianças: perspectivas teóricas e suas articulações no contexto do pensamento estratégico. RAC-Revista de Administração Contemporânea, 14(4), 722-737. 